\title{
Crop physiological response across the Chicago metropolitan region: Developing recommendations for urban and peri-urban farmers in the North Central US
}

\author{
Ross K. Wagstaff and Sam E. Wortman* \\ Department of Crop Sciences, University of Illinois at Urbana-Champaign, Urbana, IL 61801, USA \\ ${ }^{*}$ Corresponding author: swortman@illinois.edu
}

\author{
Accepted 6 November 2013; \\ First published online 13 December 2013
}

From the Field for Themed Content: Urban Agriculture

\begin{abstract}
Despite the surge of interest in urban agriculture, there have been few studies that address the biophysical challenges and opportunities of food production in urban environments. This study aims to determine the relative influence of atmospheric pollutants and microclimatic factors on the physiological response and productivity of vegetable crops across an urban-to-rural latitudinal transect in the greater Chicago metropolitan region. Data collected at each of six sites include continuous measures of atmospheric pollutants and microclimatic factors, and biweekly measures of physiological response and yield of various vegetable crops and cultivars. Preliminary data collected in early 2013 suggest that there is substantial variability in environmental factors and crop yield across this urban-to-rural transect. Results of this study will provide a scientific basis for crop adaptation to the urban environment and establish practical crop and cultivar recommendations for urban and peri-urban farmers in the North Central US.
\end{abstract}

Key words: urban agriculture, urban gardening, vegetable crops, plant ecophysiology

\section{Introduction}

Urban agriculture can be defined as all forms of agricultural production (food and non-food products) occurring within or around cities. Urban agriculture is unique from rural agriculture in that farmers have the opportunity to use or reuse urban resources (e.g., labor, materials and waste products) and in return provide agricultural products and services to urban areas ${ }^{1}$. The most common form of urban agriculture in the US is fruit and vegetable production, which occurs in home and community gardens, vacant lots, controlled environments (e.g., greenhouses) and on rooftops. While home gardening is a historically popular hobby in the US, urban agriculture is now emerging as a commercial sector of local food economies. As the concentration of people living within urban areas around the world increases ${ }^{2}$, urban agriculture may contribute to increased food security, food safety, nutrition and food equity within cities ${ }^{3,4}$. Urban food production is seen as a sustainable reuse of vacant land and greenspace in urban areas because of close proximity to consumers, efficient utilization of land resources, and community and social benefits ${ }^{5,6}$. Urban agricultural activities are already underway in major metropolitan areas of the US, but there is limited sciencebased information available to urban farmers regarding the cultivation of plants in urban environments ${ }^{7}$.

The vast majority of agricultural scientific knowledge has been obtained through field experimentation in rural growing environments, but there is increasing evidence to suggest that the urban atmospheric growing environment is substantially different from the rural environment ${ }^{7}$. Some aspects of the urban environment, including elevated ambient $\mathrm{CO}_{2}$ and temperatures, can positively influence plants via carbon fertilization effects and an effectively longer growing season ${ }^{8,9}$. However, plants may be negatively affected by elevated concentrations of atmospheric pollutants (e.g., $\mathrm{O}_{3}$, volatile organic carbons and $\mathrm{NO}_{x}$ ) and extreme heat in urban areas ${ }^{10,11}$. Atmospheric concentrations of $\mathrm{CO}_{2}$ are elevated in dense urban areas due to increased human activity and fossil fuel combustion $^{12,13}$. In the absence of heat and moisture stress, elevated $\mathrm{CO}_{2}$ has been shown to increase plant productivity and fruit yield ${ }^{14}$. Elevated $\mathrm{CO}_{2}$ can also reduce plant 
water use due to reductions in stomatal conductance, but this effect is accompanied by reduced plant transpiration that can lead to increased canopy temperature and plant stress $^{15}$.

Ozone is also elevated in and around urban areas due to a variety of anthropogenic activities, and can have phytotoxic effects on plants ${ }^{10,16,17}$. Current tropospheric ozone levels can be damaging to crop yields and future projections suggest concentrations will increase ${ }^{18}$. Plants are vulnerable to ozone damage due to the sensitivity of the photosynthetic pathway to oxidative stress ${ }^{18}$, and elevated tropospheric ozone has been shown to reduce photosynthesis and root:shoot ratio in plants ${ }^{17}$. However, large variation in ozone susceptibility has been shown among species ${ }^{19}$. Ozone is also a potent greenhouse gas that may contribute to increased thermal radiation and temperatures in cities ${ }^{20}$. Ozone concentrations and fluxes in metropolitan regions are variable due to the reactive nature of ozone, but the levels can be two to four times greater in urban areas relative to adjacent rural areas during high flux periods ${ }^{20,21}$. However, because ozone readily oxidizes nitrous oxides and other reduced materials in the urban atmospheric environment, ozone concentrations are often greater in downwind rural areas adjacent to cities ${ }^{22}$.

In addition to atmospheric pollutants, crops growing in urban environments are influenced by elevated temperatures $^{23}$, reduced wind speed $^{24}$, shading and increased moisture stress ${ }^{25}$. The elevation of temperatures in urban areas can be beneficial if it extends the growing season for farmers ${ }^{9}$ because it may provide opportunities to grow crops and cultivars not typical in the region, or to double crop and increase profitability per unit area. Unfortunately, elevated average urban temperatures are typically accompanied by extreme daytime temperatures and elevated night-time temperatures, which have been shown to limit plant growth ${ }^{26,27}$. Reduced wind speeds in urban areas are the result of the built environment, which can act as an artificial windbreak, reducing plant mechanical damage and increasing yields ${ }^{24,28}$. However, reduced wind speed can contribute to increased temperature and vapor pressure deficit (VPD). Elevated VPD in cities will increase plant transpiration and moisture stress, placing a greater demand on supplemental irrigation water ${ }^{7,25}$.

Effects of the urban atmospheric environment on plants are complex and many factors are interrelated. To better understand the complex relationship between plants and the urban environment, we established a 3-year in situ experiment in 2013 to accomplish three specific objectives: (1) characterize the atmospheric environment along an urban-to-rural latitudinal transect through the Chicago, IL metropolitan region, with regular measurements of ambient $\mathrm{CO}_{2}$, tropospheric ozone, temperature, light intensity, VPD and wind speed; (2) quantify crop and cultivar plant physiological response to altered environmental conditions along this urban-to-rural latitudinal transect; and (3) determine the relative influence of each environmental factor on crop and cultivar physiological response. Results of this study will establish a scientific understanding of crop physiological response and adaptation to the urban environment, and also provide practical crop and cultivar recommendations for the growing population of urban and peri-urban farmers in the North Central US.

\section{Materials and Methods}

Six individual research sites were established along an urban-to-rural latitudinal transect (approximately $\left.41^{\circ} 51^{\prime} \mathrm{N}\right)$ in the Chicago, IL metropolitan region in March 2013 (this marks the first year of a 3-year study). The most rural site is located in Maple Park, IL $\left(41^{\circ} 52^{\prime} 50^{\prime \prime} \mathrm{N}\right.$; $\left.88^{\circ} 33^{\prime} 41^{\prime \prime} \mathrm{W}\right)$ and the most urban site (relative to downtown Chicago) is located $72 \mathrm{~km}$ east in the East Garfield Park neighborhood of Chicago, IL $\left(41^{\circ} 53^{\prime} 15^{\prime \prime} \mathrm{N} ; 87^{\circ} 43^{\prime} 02^{\prime \prime} \mathrm{W}\right)$ (Supplementary Figure 1). At each site, 40 fabric pots ( 378.5 liters; $96.5 \mathrm{~cm}$ wide $\times 50.8 \mathrm{~cm}$ deep; Smart Pots, High Caliper Growing-Root Control, Inc., Oklahoma City, OK) were filled with a uniform nutrient sufficient soil-compost mix $(12.8 \%$ OMC; $\mathrm{pH}=8.1 ; 62 \%$ sand; $22 \%$ silt; $16 \%$ clay by texture) and equipped with drip irrigation soaker tubes (Dripworks, Inc., Willits, CA) set on a timer to deliver 9.5 liters of water per pot per day to satisfy crop water demand throughout the growing season (Supplementary Figure 2). Five soil water sensors (Watermark 200SS; Irrometer Company, Inc., Riverside, CA) were buried to a depth of $10 \mathrm{~cm}$ in random pots at each site to ensure soil moisture is maintained near field capacity and does not become limiting to crops.

The experiment is arranged in a randomized complete block design with eight replicates nested within four blocks, and ten possible crops or cultivars planted at any one time within each replication across six sites. An imagined line divided the surface of each pot in half, creating two experimental units per pot for a total of 80 experimental units per site (Supplementary Figures 3 and 4). The number of individual crops planted in each experimental unit varied by crop, depending on size, ranging from one (e.g., tomato and zucchini) to eight (i.e., onion) plants per experimental unit.

A total of 12 unique crop species or cultivars were transplanted into experimental units at each site between April 11, 2013 and July 24, 2013. Crops and cultivars included: three tomato cultivars (Solanum lycopersicum cvs. Virginia Sweets, Granadero and Sungold), two pepper cultivars (Capsicum annuum cvs. Bounty and Antohi Romanian), two cultivars of snap bean (Phaseolus vulgaris L. cvs. R123 and S156), onion (Allium cepa cv. Candy), zucchini (Cucurbita pepo cv. Safari), kale (Brassica oleracea $\mathrm{cv}$. Winterbor), beet (Beta vulgaris cv. Merlin) and Brussels sprouts (Brassica oleracea var. gemmifera cv. Diablo). Beets were double-cropped behind 
kale and Brussels sprouts were double-cropped behind sweet onion, planted on July 24, 2013 and August 1, 2013, respectively. Crop species and cultivars were selected because of previously demonstrated susceptibility to atmospheric pollutants ${ }^{29}$ and extreme weather conditions $^{30}$, differences in growth characteristics (e.g., cool season versus warm season crops $^{31}$ ), and popularity among urban farmers (unpublished data). For example, one cultivar of snap bean has demonstrated tolerance to ground-level ozone (R123), whereas the other is susceptible $(\mathrm{S} 156)^{29}$.

Plant physiological measures vary by crop, but include measures of leaf chlorophyll (atLEAF light transmittance meter; FTGreen, LLC, Wilmington, DE), leaf area index (CI-202; CID Bio-Science, Inc., Camas, WA), plant height, stem diameter, marketable yield and final plant biomass. Microclimatic factors and atmospheric pollutants are being monitored at each site in an effort to explain variability in plant physiology across sites (Supplementary Figure 5). Data collected include ambient concentrations of $\mathrm{CO}_{2}$ (SPA-5 $\mathrm{CO}_{2}$ IRGA; PP Systems, Amesbury, MA) and ozone (F12; Ozone Solutions, Inc., Hull, IA), temperature and relative humidity (CS215; Campbell Scientific, Inc., Logan, UT), wind speed (cup anemometer 18860-90; R.M. Young Comp., Traverse City, MI) and direction (wind vane 7911; Davis Instruments, Hayward, CA), and photon flux density (SP-110 pyranometer; Apogee Instruments, Inc., Logan, UT). All sensors are connected to a factor corrected data logger (CR10X; Campbell Scientific, Inc., Logan, UT) and data points are logged every $20 \mathrm{~min}$. Each site is visited by researchers at least three times per month to collect plant physiological data, harvest and download environmental data from loggers. Because all experimental sites are 2-3h from campus, we are collaborating with community volunteers and University of Illinois Master Gardeners to collect harvest data for indeterminate crops (i.e., tomato, zucchini, beans and peppers) at all sites. Volunteers were trained on harvest procedures at the beginning of the season and an experimental protocol, data sheets, scales, bags and harvest knives are stored at each site.

Preliminary yield data presented here were analyzed with a mixed models analysis of variance with site as the fixed effect, replication as the random effect, and kale yield as the response variable (Proc GLIMMIX; SAS 9.3, SAS Institute Inc., Cary, NC, USA). Daytime and night-time means of environmental data were calculated for each site (where data were available) to serve as a preliminary method of comparison, but these data have not yet been statistically analyzed. Future analyses will seek to explain variation in plant physiology and yield among sites with environmental data using multivariate methods. Partial least squares regression is one potentially suitable multivariate method that has been used previously to relate environmental data to variability in plant demography and growth among locations $^{32}$.

\section{Results and Discussion}

\section{Environmental data}

Mean daytime $(07.00-19.00 \mathrm{~h})$ and night-time (19.00-07.00 h) environmental data from the six experimental sites for the period of June 13 to July 242013 are summarized in Fig. 1. Data missing from individual sites for individual metrics were either the result of a missing instrument (e.g., only three ozone sensors were deployed in this study) or temporary sensor malfunction.

Average daytime temperature differed $<1^{\circ} \mathrm{C}$ between rural (Kuiper's) and urban (Honore St. and Garfield) sites (ranging from 25.8 to $26.5^{\circ} \mathrm{C}$ ), but night-time temperatures were more than $2^{\circ} \mathrm{C}$ warmer at the urban sites relative to the rural site, ranging from 19.5 to $21.7^{\circ} \mathrm{C}$ (Fig. 1). The substantial night-time temperature cline from urban to rural sites is consistent with the results of George et al. ${ }^{33}$. In the absence of extreme heat and plant stress, elevated night-time temperatures may accelerate plant physiological development (e.g., accumulation of thermal heat units) and lead to greater productivity in urban areas for certain crops $^{23}$. However, elevated night-time temperatures have also been shown to inhibit photosynthesis and crop yield ${ }^{27}$. Daytime solar radiation intensity ranged from $471 \mathrm{~W} \mathrm{~m}^{-2}$ at St. Charles (periurban) to $508 \mathrm{~W} \mathrm{~m}^{-2}$ at Kuiper's (rural) (Fig. 1). Light intensity did not follow a predictable spatial cline and instead seemed to be most influenced by proximity to surrounding tree canopies. The St. Charles, Cantigny and Cantata sites are surrounded by trees and reduced mean daytime solar radiation may be the result of partial light attenuation of the canopy during brief dawn and dusk hours. The $4.2 \%$ reduction in solar radiation at Garfield (urban) relative to Kuiper's (rural) in the absence of adjacent tree canopies may be the result of light attenuation by urban air pollutants (e.g., smog) ${ }^{34}$.

VPD, the difference between actual and saturated atmospheric moisture, was on average $11.5 \%$ greater at urban sites (Honore St., Garfield and Cantata) than at peri-urban sites (Cantigny and St. Charles) during daytime hours (Fig. 1). VPD increases with temperature, which helps to explain elevated daytime and night-time VPD in urban relative to peri-urban sites of this study. Elevated VPD can lead to increased plant transpiration, water stress in the absence of adequate soil moisture, and disease and pest pressure ${ }^{25}$. Wind speed generally decreased from rural to urban sites, with the exception of the Garfield site (Fig. 1). Elevated wind speed at the urban Garfield site may be related to a lower density of trees and built structures in the area, but this anomalous response requires further investigation. Bang et $\mathrm{al}^{24}$ reported increased plant productivity due to reduced wind speed in the urban environment, but this response may be specific to water-limited environments where wind can increase transpiration and plant moisture stress. Given adequate soil moisture (as is provided in this study), increased wind speed may lead to changes in plant 


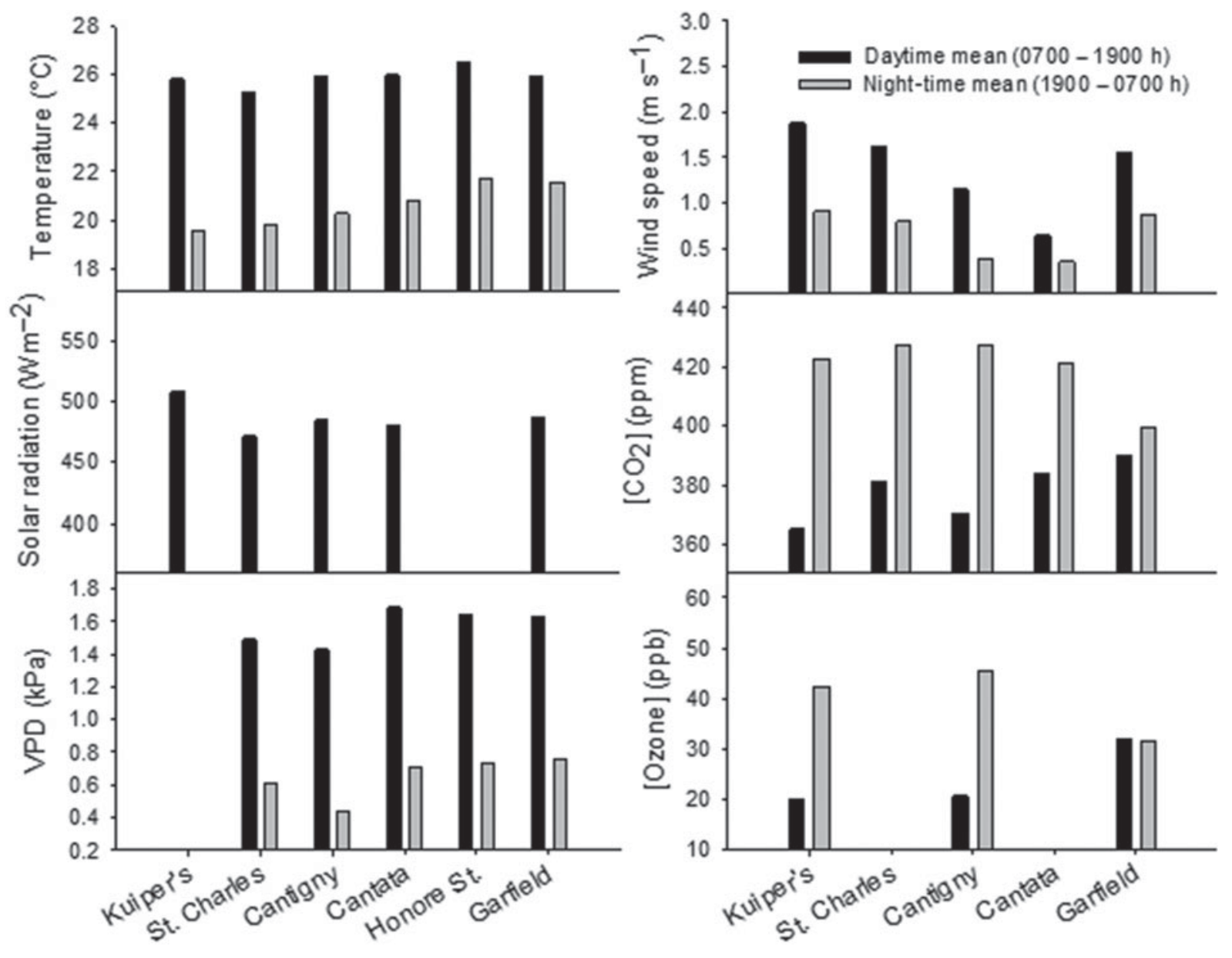

Site

Figure 1. Daytime (07.00-19.00 h) and night-time (19.00-07.00 h) means of environmental data measured between June 13, 2013 and July 24, 2013 at six sites located along a rural (Kuiper's) to urban (Cantata, Honore St., and Garfield) latitudinal transect (sites are arranged from left to right on the $x$-axis in order of decreasing distance from Chicago city center). Environmental measures include temperature $\left({ }^{\circ} \mathrm{C}\right)$, solar radiation $\left(\mathrm{W} \mathrm{m}^{-2}\right)$, VPD $(\mathrm{kPa})$, wind speed $\left(\mathrm{m} \mathrm{s}^{-1}\right), \mathrm{CO}_{2}$ concentration $(\mathrm{ppm})$, and ozone concentration (ppb). Missing data are due to the lack of a sensor at the site (e.g., ozone sensors only installed at three sites) or sensor malfunction (e.g., Kuiper's VPD).

architecture (e.g., shorter plants with thicker stems) without adverse effects on yield ${ }^{35}$.

Daytime $\mathrm{CO}_{2}$ concentrations generally were lower in rural compared to urban sites, ranging from $365 \mathrm{ppm}$ at Kuiper's (rural) to $390 \mathrm{ppm}$ at Garfield (urban). In contrast, night-time $\mathrm{CO}_{2}$ concentrations were greatest in rural and peri-urban areas, ranging from $427 \mathrm{ppm}$ at St. Charles and Cantigny (peri-urban) to $399 \mathrm{ppm}$ at Garfield (urban). Elevated night-time $\mathrm{CO}_{2}$ concentrations at rural and peri-urban sites may be related to the density of vegetation surrounding each site, because plants will respire and become a source of atmospheric $\mathrm{CO}_{2}$ at night $^{36}$. The peri-urban and rural sites in this study are surrounded by either urban forest (Cantigny) or row crop fields (St. Charles and Kuiper's), whereas the most urban site (Garfield) is surrounded by a higher density of concrete and built structures. The $25 \mathrm{ppm}$ difference in daytime $\mathrm{CO}_{2}$ concentration observed between the most urban and rural sites of this study is modest compared to the 66 and $122 \mathrm{ppm}$ urban-to-rural contrasts reported by George et al. $^{33}$ and Ziska et al. ${ }^{23}$, respectively, in the Baltimore, MD metro region. Daytime ozone concentration was greatest at the most urban site (32 ppb at Garfield) compared to the peri-urban (21 ppb at Cantigny) and rural (20 ppb at Kuiper's) sites. In contrast, night-time ozone concentrations were greatest at the peri-urban and rural sites and lowest at the urban site (Fig. 1). Elevated ozone concentrations in urban relative to rural environments have been shown to cause significant damage to plant growth $^{37}$.

\section{Kale yield}

Kale yield among sites varied depending on the harvest interval, but total yield was greatest at Garfield (the most urban site) (Fig. 2). Total yield ranged from $2723 \mathrm{~g} \mathrm{plot}^{-1}$ 


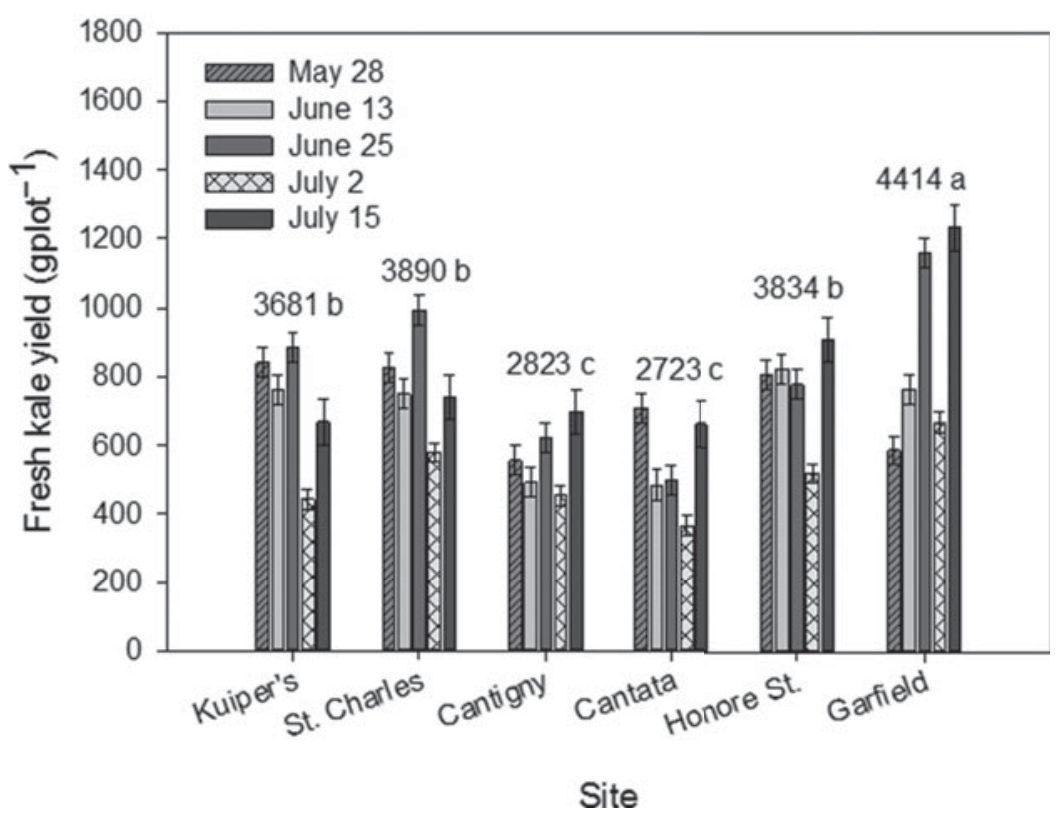

Figure 2. Fresh kale yield (g plot $^{-1} \pm$ one standard error) harvested across five dates at six sites across a rural (Kuiper's) to urban (Cantata, Honore St. and Garfield) latitudinal transect in the Chicago metropolitan region. Number above grouped vertical bars for each site is the sum of all yields and different letters indicate significant differences among sites $(\alpha=0.05)$.

at the Cantata site to $4414 \mathrm{gplot}^{-1}$ at Garfield, a difference of $38 \%$. This result was somewhat surprising given that yield at the Garfield site during the first harvest interval was comparatively lower than most sites. Yield at the Garfield site during the second harvest interval was similar to Kuiper's, St. Charles and Honore St. sites, but yield during the third, fourth and fifth harvest intervals far exceeded all other sites (Fig. 2). Yield across all harvest intervals was consistently lowest at the Cantata and Cantigny sites (urban and peri-urban sites, respectively).

After analysis of preliminary environmental data, it was not immediately clear why kale yields were reduced at the Cantata and Cantigny sites. Differences in mean daytime solar radiation among sites appeared minor, but brief shading of at least one replicate block at both of these sites during dawn or dusk hours may be responsible for this negative yield response. A second pyranometer will be installed to quantify variability in light intensity gradients within sites that may be driving yield differences. If the $38 \%$ yield reduction can be attributed to partial light attenuation at these sites, this result would emphasize the importance and challenge of finding urban agriculture sites with access to full sunlight throughout the day and the need to develop shade-tolerant cultivars of vegetable crops for urban agriculture. Reductions in early yield of kale at the most urban site (despite the greatest final yield), may be related to elevated daytime ozone concentrations. Young plant seedlings may be more sensitive than juvenile and mature plants to elevated ozone concentrations ${ }^{37}$. Indeed, interveinal leaf chlorosis typical of phytotoxic pollutant stress was observed during early kale growth at the Garfield site.
Relationships between kale yield (and other crops) and environmental measures are complex and will require several years of data and multivariate statistical models to understand and explain a portion of the variability among sites. Building a model to understand how microclimatic factors and atmospheric pollutants influence crop physiology and yield is the central aim of this project and results will provide a scientific basis for site, crop and cultivar selection for urban and peri-urban cropping systems. In the long term, results of this project will help to increase the profitability of urban food production in the North Central US - an outcome necessary for the sustained growth of the urban agriculture movement.

The supplementary materials for this article can be found at http://www.journals.cambridge.org/raf

Acknowledgements. The authors would like to thank Michael Douglass for his assistance in managing this trial.

\section{References}

1 Mougeot, L.J.A. 2000. Urban agriculture: Definition, presence, potentials, and risks. In N. Bakker, M. Dubbeling, S. Gündel, U. Sabel-Koschella, and H. de Zeeuw (eds). Growing Cities, Growing Food: Urban Agriculture on the Policy Agenda. Deutsche Stiftung für internationale Entwicklung (DSE). Zentralstelle für Ernährung und Landwirtschaft, Feldafing, Germany. p. 1-42.

2 United Nations, Department of Economic and Social Affairs, Population Division. 2012. World Urbanization 
Prospects: The 2011 Revision. Available at Web site http:// esa.un.org/unup/CD-ROM/Urban-Rural-Population.htm (accessed November 28, 2013).

3 Mok, H.-F., Williamson, V.G., Grove, J.R., Burry, K., Barker, S.F., and Hamilton, A.J. 2013. Strawberry fields forever? Urban agriculture in developed countries: A review. Agronomy for Sustainable Development DOI: 10.1007/ s13593-013-0156-7.

4 Armar-Klemesu, M. 2000. Urban agriculture and food security, nutrition and health. In N. Bakker, M. Dubbeling, S. Guendel, U. Sabel Koschella, and H. de Zeeuw (eds). Growing Cities, Growing Food, Urban Agriculture on the Policy Agenda. DSE, Feldafing. p. 99-117.

5 Colasanti, K.J.A., Hamm, M.W., and Litjens,, C.M. 2012. The city as an "agricultural powerhouse"? Perspectives on expanding urban agriculture from Detroit, Michigan. Urban Geography 33:348-369.

6 Lovell, S.T. 2010. Multifunctional urban agriculture for sustainable land use planning in the United States. Sustainability 2:2499-2522.

7 Wortman, S.E. and Lovell, S.T. 2013. Environmental challenges threatening the growth of urban agriculture in the United States. Journal of Environmental Quality 42:1283-1294.

8 Long, S.P., Ainsworth, E.A., Rogers, A., and Ort, D.R. 2004. Rising atmospheric carbon dioxide: Plants FACE the future. Annual Review of Plant Biology 55:591-628.

9 Zhang, X.Y., Friedl, M.A., Schaaf, C.B., and Strahler, A.H. 2004. Climate controls on vegetation phenological patterns in northern mid- and high latitudes inferred from MODIS data. Global Change Biology 10:1133-1145.

10 Mansfield, T.A. and Freer-Smith, P.H. 1981. Effects of urban air pollution on plant growth. Biological Reviews 56:343-368.

11 Taha, H. 1997. Urban climates and heat islands: Albedo, evapotranspiration, and anthropogenic heat. Energy and Buildings 25:99-103.

12 Grimmond, C.S., King, T., Cropley, F., Nowak, D., and Souch, C. 2002. Local-scale fluxes of carbon dioxide in urban environments: Methodological challenges and results from Chicago. Environmental Pollution 116(Suppl. 1):S243-S254.

13 Wentz, E.A., Gober, P., Balling, R.C., and Day, T.A. 2002. Spatial patterns and determinants of winter atmospheric carbon dioxide concentrations in an urban environment. Annals of the Association of American Geographers 92:15-28.

14 Leakey, A.D.B., Ainsworth, E.A., Bernacchi, C.J., Rogers, A., Long, S.P., and Ort, D.R. 2009. Elevated $\mathrm{CO}_{2}$ effects on plant carbon, nitrogen and water relations: Six important lessons from FACE. Journal of Experimental Botany 60:2859-2876.

15 Bernacchi, C.J., Kimball, B.A., Quarles, D.R., Long, S.P., and Ort, D.R. 2007. Decreases in stomatal conductance of soybean under open-air elevation of $\left[\mathrm{CO}_{2}\right]$ are closely coupled with decreases in ecosystem evapotranspiration. Plant Physiology 143:134-144.

16 Agrawal, M., Singh, B., Rajput, M., Marshall, F., and Bell, J.N. 2003. Effect of air pollution on peri-urban agriculture: A case study. Environmental Pollution 126: 323-329.

17 Gregg, J.W., Jones, C.G., and Dawson, T.E. 2006. Physiological and developmental effects of $\mathrm{O}_{3}$ on cottonwood growth in urban and rural sites. Ecological Applications 16:2368-2381.

18 Fuhrer, J. 2009. Ozone risk for crops and pastures in present and future climates. Naturwissenschaften 96:173-194.

19 Krupa, S.V., McGrath, M.T., Andersen, C.P., Booker, F.L., Burkey, K.O., Chappelka, A.H., Chevone, B.I., Pell, E.J. and Zilinskas, B.A. 2001. Ambient ozone and plant health. Plant Disease 85:4-12.

20 Kleinman, L.I., Daum, P.H., Imre, D., Lee, Y.-N., Nunnermacker, L.J., Springston, S.R., Weinstein-Lloyd, J., and Rudolph, J. 2002. Ozone production rate and hydrocarbon reactivity in 5 urban areas: A cause of high ozone concentration in Houston. Geophysical Research Letters 29:105-1-105-4.

21 Chameides, P., Kasibhatla, P., Yienger, H., and Levy, H. 1994. Growth of continental-scale metro-agro-plexes, region ozone polution, and world food production. Science 264: 74-77.

22 Isaksen, I.S.A., Hov, O., and Hesstvedt, E. 1978. O generation over rural areas. Environmental Science and Technology 12:1279-1284.

23 Ziska, L.H., Gebhard, D.E., Frenz, D.A., Faulkner, S., Singer, B.D., and Straka, J.G. 2003. Cities as harbingers of climate change: Common ragweed, urbanization, and public health. Journal of Allergy and Clinical Immunology 111:290-295.

24 Bang, C., Sabo, J.L., and Faeth, S.H. 2010. Reduced wind speed improves plant growth in a desert city. PLoS ONE 5: e11061.

25 Cregg, B.M. and Dix, M.E. 2001. Tree moisture stress and insect damage in urban areas in relation to heat island effects. Journal of Arborculture 27:8-17.

26 Baker, L.A., Brazel, A.J., Selover, N., Martin, C., McIntyre, N., Steiner, F.R., Nelson, A., and Musacchio, L. 2002. Urbanization and warming of Phoenix (Arizona, USA): Impacts, feedbacks, and mitigation. Urban Ecosystems 6:183-203.

27 Prasad, P.V.V., Pisipati, S.R., Ristic, Z., Bukovnik, U., and Fritz, A.K. 2008. Effect of nighttime temperature on physiology and growth of spring wheat. Crop Science 48:23722380.

28 Hodges, L., Suratman, M.N., Brandle, J.R., and Hubbard, K.G. 2004. Growth and yield of snap beans as affected by wind protection and microclimate changes due to shelterbelts and planting dates. HortScience 39:9961004.

29 Burkey, K.O., Miller, J.E., and Fiscus, E.L. 2005. Assessment of ambient ozone effects on vegetation using snap bean as a bioindicator species. Journal of Environment Quality 34:1081-1086.

30 Luo, Q. 2011. Temperature thresholds and crop production: A review. Climatic Change 109:583-598.

31 Maynard, D.N. and Hochmuth, G.J. 2007. Knott's Handbook for Vegetable Growers. 5th ed. John Wiley and Sons, Hoboken, NJ.

32 Wortman, S.E., Davis, A.S., Schutte, B.J., Lindquist, J.L., Cardina, J., Felix, J., Sprague, C.L., Dille, J.A., Ramirez, A. H.M., Reicks, G., and Clay, S.A. 2012. Local conditions, not regional gradients, drive demographic variation of giant ragweed (Ambrosia trifida) and common sunflower (Helianthus annuиs) across northern U.S. maize belt. Weed Science 60:440-450. 
33 George, K., Ziska, L.H., Bunce, J.A., and Quebedeaux, B. 2007. Elevated atmospheric $\mathrm{CO}_{2}$ concentration and temperature across an urban-rural transect. Atmospheric Environment 41:7654-7665.

34 Horvath, H. 1993. Atmospheric light absorption-A review. Atmospheric Environment A: General Topics 27:293-317.

35 Henry, H.A.L. and Thomas, S.C. 2002. Interactive effects of lateral shade and wind on stem allometry, biomass allocation, and mechanical stability in Abutilon theophrasti (Malvaceae). American Journal of Botany 89:1609-1615.

36 Pataki, D.E., Bowling, D.R., and Ehleringer, J.R. 2003. Seasonal cycle of carbon dioxide and its isotopic composition in an urban atmosphere: Anthropogenic and biogenic effects. Journal of Geophysical Research: Atmospheres 108:4735, doi: 10.1029/2003JD003865.

37 Pandey, J. and Pandey, U. 1994. Evaluation of air pollution phytotoxicity in a seasonally dry tropical urban environment. Environmental Monitoring and Assessment 33:195-213. 